\title{
Maintenance of Manufacturing Machinery
}

National Cancer Institute

\section{Source}

National Cancer Institute. Maintenance of Manufacturing Machinery. NCI Thesaurus.

Code C139497.

Problems caused by failure to maintain manufacturing equipment used to produce the device. 